\title{
Knowing the Country
}

\section{Eve Vincent}

Between 2000 and 2005 I travelled from Melbourne to South Australian outback opal mining town Coober Pedy many times. Sometimes I went by bus, sometimes by car. I got to know the road. We passed salt lakes, sparse scrub, lines of trees that signified creek. The bitumen's edge met grass, then grey dirt, then grainy red sand, then white dust. 'Strong stories change the way people think', says anthropologist Deborah Bird Rose. ${ }^{1}$ I have road-tripped thousands of kilometres because of this story. I'm not sure how to begin it. And I'll never get sick of the ending.

July 2004: damper, jam and cream

On 14 July 2004 Prime Minister John Howard announced that the national low-level nuclear waste dump planned for South Australia had been scrapped. Outmanoeuvred by Mike Rann's anti-dump state Labor government at every turn, Howard caved in after realising that he could not continue to ignore sustained public opposition. Howard was evidently pissed off, but marginal Adelaide seats were at stake in the 2004 Federal Election.

In late July I visited Coober Pedy at the same time as Rann passed through for a series of community meetings. At present Rann is associated with enthusiastic policy initiatives that aim to expand uranium mining in his mineral-rich state, and with an internal push to see Labor's anti-uranium mine position overturned. That sunny, winter morning in 2004 Rann came to Umoona Aboriginal Aged Care Centre for celebratory damper, jam and cream. Rann's a smooth talker, but I had to believe him when he said that throughout the protracted waste dump battle he treasured the letters of support he received from the Kupa Piti Kungka Tjuta, a council of senior 
Aboriginal women based in Coober Pedy.

After all, how many letters to the premier sign off with the intensity of Mrs Eileen Unkari Crombie, 'One of the Kupa Piti Kungka Tjuta who always sticks up for a man like you til the end of the world'? Mrs Crombie wrote to Rann after seeing him on the TV:

Keep fighting! Don't give up and we won't give up. Keep fighting because kids want to grow up and see the country when we leave them, when we pass on. They'll take it on. Hope they'll fight like we fellas for the country. We don't want to see the irati-poison, come back this way. We're not going to give up. ${ }^{2}$

The Kupa Piti Kungka Tjuta (KPKT) is a council comprising senior Anangu (Aboriginal) women from Antikarinya, Yankunytjatjara and Kokatha countries. Kupa Piti, according to some local versions, is Yankunytjatjara for 'white men's holes'; the non-Indigenous place name 'Coober Pedy' is based on the transliteration of this description. ${ }^{3}$ Kungka means woman, and tjuta means many. The Kungka Tjuta came together in Coober Pedy in the early 1990 s to revive traditional women's culture: to ensure the transmission of stories and knowledge; the continuation of cultural practices; and the maintenance of their responsibilities to country. The old women were worried that their kids and grandkids were growing up in town, whereas they had grown up travelling the country, and learning the country. They say that they wanted to give their 'children and grandchildren something more than video games, drinking and drugs, and walking the street'. ${ }^{4}$

In early 1998 the federal government announced it planned to build a radioactive waste repository within an arid region of South Australia, which encompassed the traditional countries of Antikarinya, Yankunytjatjara and Kokatha people. The Kungkas responded with an announcement of their own. This 'statement of opposition' became a sort of mission statement for their six-year-long anti-dump campaign, which they called Irati Wanti - the poison, leave it. The Kungkas' letters and statements are now collected in a book published by the campaign office, Talking Straight Out: Stories from the 
Irati Wanti Campaign. The statement of opposition reads:

We are the Aboriginal Women. Yankunytjatjara, Antikarinya and Kokatha. We know the country. The poison the Government is talking about will poison the land. We say, 'No radioactive dump in our ngura - in our country.' It's strictly poison, we don't want it. ... We were born on the earth, not in the hospital. We were born in the sand ... We really know the land. From a baby we grow up on the land. Never mind our country is the desert, that's where we belong. And we love where we belong, the whole land. We know the stories for the land.

I became involved in a small greenie support group for the Kungkas, undertaking awareness- and fund-raising for them in cities, where campaigns are won and lost. A good friend moved to Coober Pedy to coordinate things from there and I visited every winter.

To a history student like me this statement, and subsequent ones, captured my imagination. It continued:

All of us were living when the Government used the country for the Bomb ... The smoke was funny and everything looked hazy. Everybody got sick ... The Government thought they knew what they were doing then. Now, again they are coming along and telling us poor blackfellas, 'Oh, there's nothing that's going to happen, nothing is going to kill you.' And that will still happen like that Bomb over there.

The 'Bomb' referred to is Totem One, detonated by the British Government on 15 October 1953 at Emu Fields, a flat claypan 28o kilometres north of Coober Pedy. Totem One was the first mainland test carried out by the British, with the support of the Australian Government and the involvement of Australian Army personnel, as part of an atomic weapons testing program undertaken between 1952 and 1963 at three separate Australian locations-Monte Bello Islands, Emu Fields and the better known Maralinga Range.On the morning of 15 October a dense radioactive cloud travelled over Anangu 
communities and pastoral stations in the Coober Pedy region. ${ }^{5}$ The eerie, deadly 'black mist' it produced was investigated by the 1984 Royal Commission into British Nuclear Tests in Australia, as a result of Yankunytjatjara elder Yami Lester's insistence.

In the early 1980 sester, who attributes his blindness to exposure to radioactive fallout, contacted Adelaide newspaper The Advertiser with his story and the Pitjantjatjara Council joined atomic ex-servicepersons, many of whom were dying of cancer, to call for a royal commission. ${ }^{6}$ In a front-page article, Lester told Advertiser journalist Robert Ball that the Yankunytjatjara camp at Wallatinna was enveloped by a 'black mist' that rolled through the mulga scrub and 'brought death'. 7 Within forty-eight hours of hearing an explosion in the south 'everyone in the camp was debilitated by uncontrollable vomiting and diarrhoea'. A skin rash broke out, and healthy children started going blind; some partially recovered their sight, others did not. ${ }^{8}$

Kungka Tjuta member Mrs Eileen Kampakuta Brown describes what she saw:

The smoke caught us. We got up in the morning from the tent ... everyone had red eyes. The smoke caught us - it came over us. We tried to open our eyes in the morning but we couldn't open them. We had red eyes and tongues and our coughing was getting worse. We were wondering what sort of sickness we had. There were no doctors, only the station bosses. All day we sat in the tent with our eyes closed. Our eyes were sore, red and shut. We couldn't open them ... All people got sick right up to Oodnadatta ... we all got sick. ${ }^{9}$

Angelina Wonga, another Kungka Tjuta member was camped at Wantjapita with her family. She was 'sitting down'. She describes:

We seen a bomb went out from the South. And said, eh? What's that? And then we see the wind blowing it to where we were sitting down. That was the finish of mother and father. They all passed away through that. I was the only 
one left. We'd been travelling on camels. I let all the camels go ... I lost everything. ${ }^{10}$

The Royal Commission found that Ernest Titterton, who was responsible for the safety of the Australian public, assured Prime Minister Menzies that 'no habitations or living beings will suffer injury to health from the effects of the atomic explosions proposed for the Totem trials'. ${ }^{11}$ Both Totem tests were delayed owing to easterly winds that would have contaminated the Emu 'campsite', by then a temporary town supporting four hundred inhabitants. ${ }^{12}$ Totem One was eventually detonated a week late under unusual meteorological conditions. The day had no wind shear, exactly the kind of conditions highlighted as dangerous by a preparatory report. ${ }^{13}$ The Totem One cloud rose to a height of fifteen thousand feet after three minutes and drifted northwest without its radioactive particles dispersing. It was still clearly visible twenty-four hours after detonation. ${ }^{14}$ The Report of the Royal Commission concluded: 'Totem One was carried out under wind conditions that the [preparatory] report had shown would produce unacceptable levels of fall-out', a decision that 'failed to take into account the existence of people at Wallatinna and Welbourne Hill'. ${ }^{15}$ These people's 'existence' was known to the testing team via Long Range Weapons Organisation (LRWO) employee Walter MacDougall's patrols. Lester summarises: 'We don't know the times and the days. We had no clocks or calendars in the bush. But the Royal Commission found that the weather was not right that day, too dangerous, and the scientists should have known.' ${ }^{16}$ Explaining the decision to detonate, Heather Goodall, researcher for the Pitjantjatjara Council during the Royal Commission, notes that the British team was under pressure from their government to demonstrate the 'dramatic success' of Britain's nuclear weapons capability. During the Cold War arms race 'a risk to the health of a small number of Aboriginal people seemed a small price to pay for British pride'. ${ }^{17}$

The Royal Commission, Graeme Turner says, 'represented the completion of a ritual of separation [from Britain] which had to be performed if Australia was finally to be in its own place'. ${ }^{18}$ Turner critiques the popular meaning the Royal 
Commission gave the atomic testing program: the story of the British-Australian colonial relationship, between the centre of Empire and a peripheral, anglophile Australian Government. Intent on exposing 'the devastating material effects of colonial domination', the Royal Commission grossly 'misrepresented the Australian Government's degree of culpability.'. colonial relationship between Indigenous people and the Australian Government was 'submerged under the weight of another story'. ${ }^{20}$

I contend that, in eliding this other story, which would necessarily tell of an ongoing relationship between the Australian state and Indigenous people, the Royal Commission enacted another ritual of separation, that of the past from the present. When the Kungka Tjuta 'testify', the past is recalled, analysed and related for the purpose of affecting the present. The remembering and re-telling of 'Bomb testimonies' remained a priority throughout the Irati Wanti campaign; I was drawn to investigate this insistent movement between past and present.

\section{July 2002: straight roads}

We go out with some of the Kungkas to help pick a strong-smelling spindly plant, irmangka irmangka, bush medicine that we greenies will later bottle, market and sell in Melbourne. 'Grandmothers been making 'em since a long long time ago', reads the label. Its base is goanna fat or more often margarine. The Kungkas opt to travel in the 'flash car' and three of us tail them in my battered ute. The landscape blurs out the open window. At one point our convoy pulls over suddenly and I ask the Kungkas in the other car 'how much further?' 'Not far' assures Mrs Austin. 'Long way' mutters Mrs Crombie.

That night, sunburnt and dusty, feeling queasy after my first taste of roasted maku (witchetty grub), I ask the others what was talked about in the 'flash car'. Most of the conversation was in language, but the Kungkas also spoke in English in order to teach things to the greenies. Repeatedly, they pointed out where the new Stuart Highway, paved in 1980, crossed the route of the old, which meandered from station to station. Occasionally they'd sigh and complain, 'This road. Long, 
straight road. Boring road.'

Throughout colonial history, the desert has been thought of, and treated as, a remote wasteland. In Rosyln Haynes's Seeking the Centre she depicts the arid interior as an exemplary 'blank space', restlessly reconstituted by colonial fears and fascinations, as alternately nightmarish and utopian. ${ }^{21}$ Early explorers' accounts depicted the desert as a vast, geographically uniform and featureless wilderness. Haynes notes: 'The changelessness ascribed to the desert was also attributed to its Indigenous inhabitants; both were seen as primitive, obdurate and inimical to civilisation. ${ }^{22}$ This point becomes important when we consider that, for Australia, the atomic testing program represented a distinctly modern experience, a moment of post-war national maturation.

Comparing Indigenous and non-Indigenous understandings of place and space, Stephen Muecke focuses on the role of naming in the re-spatialisation of the continent. Muecke contends that Indigenous people charted the country in as much detail as a city street directory provides: 'the number of Aboriginal place-names still exceeds the number of names bestowed by the colonisers'. According to Muecke 'parts of the sandy deserts of the centre, which we tend to call "unsettled" areas are still just as densely named as other parts of Australia'.23

Contemporary road maps of the centre owe much to the work of the surveyor Len Beadell, whose popular memoirs provide a particularly rich source of colonising spatial narratives. ${ }^{24}$ Beadell 'blazed' the east-west road across the centre, the Gunbarrel highway, named after Beadell's Gunbarrel Road Construction Party, who 'liked [their] roads straight'. ${ }^{25}$ His memoirs repeatedly evoke the desert as 'limitless', 'lonely', 'desolate', 'unexplored', a 'vast wasteland' and 'virgin bush'.

In 1947, when Beadell was approached by the LRWO about the potential for a rocket range, which included a diagonal corridor across one and a half thousand miles of country between Woomera and Broome, he replied 'I know a million square miles of nothing. ${ }^{26}$ Beadell went on to survey and identify appropriate detonation sites for the British atomic testing program. He constructed a network of access roads 
through central Australia, many of which he named after his kids. Reflecting on his life's work, Beadell has said that he is proud to have 'opened up' four thousand square miles 'that hadn't been touched by anyone since the world began'. ${ }^{27}$

I see Beadell as a kind of nuclear-age nomad, methodically recording longitude and latitude readings and making topographical notes, his travelogue guided by modern spatial technology - the compass and the Land Rover's trip speedo. Of course, Beadell's reconnaissance missions brought him into contact with numerous Indigenous communities. His name often appears on photo credits of Anangu family groups and individuals in books about his time period. ${ }^{28}$ Yet Beadell interprets signs of Indigenous ceremonial and social life as objects of primitive interest, 'mysterious' remnants discarded in a pre-historic landscape. ${ }^{29}$

In Blast the Bush, Beadell's story reaches an 'atomic climax', which marks the beginning of 'historic' time in the desert. Blink and you'd miss it - in a microsecond Totem One vaporised the hundred-foot-high steel bomb tower. With his back to the detonation, Beadell observed a 'blinding flash' that lit the horizon line, and felt a wave of intense heat. $\mathrm{He}$ then turned to the mushroom cloud when a spontaneous joke was played on the gathered media. Someone pointed to the cloud's shape and exclaimed 'a perfect portrait of a myall blackfeller written in the atomic dust; the new and the old have come together today'. ${ }^{\circ}$ While Beadell recounts this scene enthusiastically, other recollections of the Totem One blast are disturbing. In a submission to the Royal Commission ex-serviceman Jim Balcombe described 'a searing flash of light which came through from behind me, through the back of my head, it felt as if my eyeballs had been thrown out in front of my body'. Balcome was instructed to run, but he was picked up by the bomb and thrown thirty-five feet sideways. ${ }^{31}$

As Beadell determines, marks, bulldozes and names a grid of straight lines across the desert, he conjoins the practice of re-spatialisation with another kind of overlaying. A country 'empty' of history 'makes history'. Today of course, thanks to Len, the desert is 'known' rather than 'the unknown', 'mapped' rather than 'blank'. But how was the desert already known, already mapped? 
Oral histories from the Western Desert are densely saturated with place names, relate long journeys and refer to constant travelling. Anangu people used to 'walk everywhere ... walk to one place and then to another'. ${ }^{22}$ This walking was done barefoot and linked an extensive network of water sources. Jessie Lennon remembers her parents: 'travelling all the time, walking from one rock-hole to another, visiting people. They did not know anything about whitefellas.'33 Similarly, Kungka Tjuta member Ivy Makinti Stewart remembers 'living at Ernabella ... There were no bores, no store, we would get water from the creek and eat bush food. My father would go out hunting with spears, no rifle then.' Mrs Stewart and her family 'travelled every way through that country, walking and carrying our swags'. 34

As an adult Mrs Lennon - who grew up with Kungka Tjuta member Mrs Eileen Wani Wingfield - moved not from 'camp to camp' as her parents did, but between bush camp and ceremonial life, pastoral stations, missions and ration depots. Rations in the northwest were most commonly issued in exchange for work by doggers and station owners. Lester's childhood reminiscences also demonstrate that movement was no longer done just by tjina:

After a while (living traditional way) we came back to the station, and Kantji [Lester's father] got a job, looking after cattle and shepherding sheep ... Kantji walked the sheep, while we rode on wagons pulled by camels. From Wentinna we moved down to Mt. Willoughby where Kantji worked for a while, then southeast to Evelyn Downs. From Evelyn Downs we travelled to Arckaringa where Kantji did some shearing ... From Arckaringa we'd ride back on the trucks to Wentinna and from there we'd walk to Wallatinna, south of Granite Downs. We'd follow the creek up to the hills and walk across the bush, where our people knew the places and were able to find water in the rockholes, claypans and swamps..$^{35}$

Lester's narrative connects a series of known places and captures constant movement between Indigenous and nonIndigenous economies. 
Collecting dingo scalps for itinerant non-Indigenous 'doggers' was a common type of casual work for Indigenous people in the north of South Australia from the 1930 s and provided an ease of mobility between Indigenous and non-Indigenous economies. Dingoes were taking sheep and calves on pastoral properties, and the South Australian Government purchased the scalps. Kungka Tjuta member, Mrs Emily Munyungka Austin, 'used to move around a lot when Dad was buying dingo skins'. ${ }^{36}$ Mrs Austin's father, Jim Lennon, was Irish and made a living by trading skins for tea, sugar, flour and clothes, with Indigenous scalp collectors. Lennon sold the skins to the police, who then burnt them.

I came to think of movement as a tactical spatial practice, which allowed for the maintenance of relationships between places along what Muecke calls 'the deep Indigenous narrative lines', which have been overlaid with 'another grid of lines'. ${ }^{37}$ In the contemporary setting, Anangu people continue to move-hitching, in dodgy cars, in the church bus, in Toyota troopies on bush trips - with an energy and frequency that is astounding, considering the age of the people I know. They move across the country to visit people and maintain relationships. And the Kungka Tjuta travelled the whole country, to Adelaide, Melbourne and Sydney, in order to stand up for country.

When the federal government designated the South Australian desert as a site for waste in 1998 it revived, or perhaps more accurately relied on, a powerful discursive formation - that of the desert as empty, dead and disused space. The colonial imagination constructed the desert as a remote wasteland. This dominant understanding of the desert obfuscates another. To the Anangu who inhabit the desert, this 'dead space' is a network of known places. It is life sustaining, and full of meaning - crisscrossed with everyday, historic and personal stories, as well as dreaming tracks.

Deborah Rose and Heather Goodall have shown that Indigenous histories make sense out of colonial experiences by presenting very different versions to the dominant account of the past. Historical events as they are recalled in community memory may be both sequenced in a way other than is usually demanded by narrative history, and interpreted in a way that 
undermines the meanings drawn from the dominant interpretation of that history. For Rose, the differences are 'irrelevant in a fundamental sense'. The Yarralin people's Captain Cook stories, for example, are a 'vehicle for analysis'; they are a succinct summation of colonial relationships structured by domination and destruction..$^{38}$

The Kungkas' statements and letters do not represent past experiences in a way that upsets, or contradicts, the accepted chronology of historical events. Their claims about the effects of the Totem One bomb are substantiated by non-Indigenous accounts of the past. But, like the Yarralin, the Kungka Tjuta present a powerful case study in remembrance. The Kungka Tjuta employ a particular narrative device, drawing the past into the present, for the purpose of affecting the future. The Captain Cook 'moral saga' has a pedagogical function: it is a dialogue between two moral systems. According to Rose the moral system of Cook, which is shared by the nonIndigenous colonisers, represents immoral law. ${ }^{39}$ It is a law of domination and destruction, contrasting with Yarralin law, which is 'directed toward life, towards the maintenance of living systems'.40 The Irati Wanti campaign evidences the Kungkas' desire to maintain their part of the world, the South Australian desert, as a life-giving system. The Kungkas' letters and statements demonstrate a world-view that is directed toward life. They venerate water, which is life sustaining, and warn of the destructive capabilities of the irati, the poison.

The Kungkas' statements and letters also provide an interpretation of the relationship between 'the Government' and Anangu people, as structured by domination, destruction and, importantly, resistance. Within the Yarralin history of Cook the term 'government' is conceptualised as 'something inflicted upon [Yarralin people] from the outside, which they [have been] powerless either to change or evade'. ${ }^{41}$ Within the Kungka Tjuta's statements and letters 'the Government' is also conceptualised as the locus of destructive power and a profoundly frustrating source of ignorance. In the Kungkas' letters and statements capital G 'Government' is a shorthand reference for past and present regimes. I also understand it to conflate actual structures of power with powerful ideas. As the campaign continued and the Kungkas became more involved 
in bureaucratic processes, such as environmental assessments, they were more likely to note specificities, criticising particular politicians and responding to their statements. The current federal government was chastised for eliding the responsibilities that come with power, such as listening and responding.

The Kungka Tjuta did not accept they were powerless to change the course of the waste repository project 'the Government' planned to impose on them. Talking and travelling became methods of articulating counter-narratives, which radically disrupted the federal government's unconvincing story. These counter-narratives resonated with many nonIndigenous Australians and forced an epistemological contest between different ways of knowing the country. And, out of that contest, the Kungkas emerged: 'Happy now-Kungka winners. We are winners because of what's in our hearts, not what's on paper.' They get the last word:

People said that you can't win against the Government. Just a few women. We just kept talking and telling them to get their ears out of their pockets and listen. We never said we were going to give up. We told Howard you should look after us, not try and kill us. Straight out. We always talk straight out. In the end he didn't have the power, we did. ${ }^{42}$

\section{Reflection}

This essay is based on my Honours thesis, which was written in the Department of History at the University of Melbourne and based on my involvement in an environmental campaign. The KPKT sought a relationship with environmental organisations and actors, whose resources would augment their own vocal opposition to the proposed nuclear waste dump. The Kungkas travelled to Melbourne to forge such an alliance in 1998 and I became aware of them soon after, first travelling to Coober Pedy in 2000. A series of serendipitous events led me to Ten Mile Creek, a camp consisting of humpies and a rudimentary shed just out of town. Here I met several of the Kungkas for the first time, camping and making cups of hot black tea, stirring in the powered milk.

I see now that this encounter shaped the future direction of my work in two specific ways. First, this initial trip dispelled any 
images I might have then held about extant, discrete, culturally different Aboriginal worlds in Australia's deserts. This trip taught me about the mutual constitution and imbrication of Aboriginal and non-Aboriginal lives, economies, histories, images and ideas. For example: I spent an afternoon squeezing yellow acrylic paint out of a tube, carefully coating quandong seeds to string as necklaces sold in Coober Pedy as traditional objects, with the Kungkas heaped under blankets, napping beside us. Who, exactly, was engaged in the task of cultural reproduction? Moments like these were commonplace: greenies' desires to experience this difference seemed, to me, to be constantly disappointed. A friend adopted a camp dog and wanted the Kungkas to bestow its name. She wished for it to be indigenised. The Kungkas were adamant it be called 'Lassie'.

And yet, these were women who 'knew the stories' and songs for specific jukurrpa (dreaming) sites. Some spoke English only reluctantly. Some signed their (sometimes imploring, sometimes caustic) letters with carefully made crosses. I struggled to form friendships across radically different ways of being within the many trips I made out there. The colonial relation, the distance and time inhibited these relations. So, second, when I later returned to academic study I gravitated towards anthropology, with its powerful invitation to commit time to the development of deeper relationships, and which ultimately offered the experience of being personally transformed by this commitment.

'Born in the bush' in around 1932, Mrs Eileen Kampakuta Brown, that gentle woman, passed away in Coober Pedy in 2012. Mrs Eileen Unkari Crombie, born in 1935, also passed away in 2012. Mrs Angelina Wonga is 'finished' now too. Mrs Eileen Wani Wingfield passed away at home in Port Augusta in August 2014. A stalwart of the Kungka Tjuta council, she had lain in front of bulldozers in the early 1980 s to protest the construction of the gargantuan Olympic Dam copper and uranium mine at Roxby Downs.

I last saw Mrs Emily Austin in Port Augusta in July 2014. I was travelling with a friend from those earlier days. 'Kundi!' (Aunty) we called out to her as the kids and the two of us spilled onto her gravel front yard. 'Good to see you fellas again,' she said, squeezing us tight. We ate her sweet biscuits, sitting in the full sun outside, admiring the bright flowers she grew in pots. For many years now my travels and research have taken me west from Port Augusta. On that day I sat with my tea, sensing all that lay beyond the northern 
edges of town: the gibber plains, the silky desert peas, the shell-pink apparitions that turned to salt, and that road, that well-travelled road, shooting north.

\section{Notes}

Deborah Bird Rose, 'Morality and Captain Cook', in Bain Attwood and Fiona Magowan (eds), Telling Stories: Indigenous History and Memory in Australia and New Zealand, Allen \& Unwin, Sydney, 2001, p. 61. Kupa Piti Kungka Tjuta, Talking Straight Out: Stories from the Irati Wanti Campaign, Alapalatja Press, Coober Pedy, 2005, p. 68. Coober Pedy, compiled and edited by Michele Madigan, Aboriginal Studies Press, Canberra, 2000, p. 47.

4 Talking Straight Out, p. 6.

5 'Operation Totem', in The Report of the Royal Commission into British Nuclear Tests in Australia, vol. 1, Australian Government Publishing Service, Canberra,1985, 6.4.1-16, pp. 174-94.

6 The Pitjantjatjara council at this time represented Pitjantjatjara, Yankunytjatjara and Ngaanyatjara peoples. Anti-bases Campaign, Weapons in the Wilderness: The Exploitation of the North-west of South Australia, Anti-bases Campaign-South Australia, Adelaide, 1991, p. 19. Robert Ball, David English and Peter de Ionno, 'A "Black Mist” that Brought Death', The Advertiser, 3 May 1980, p. 1.

8 Ball, English and de Ionno, p. 1. See also Robert Ball, 'A “Devil Spirit” That Didn't Go', The Advertiser, 3 May 1980, $\mathrm{p} 1$.

9 Talking Straight Out, p. 92.

10 Ibid., p. 91.

11 Report of the Royal Commission into British Nuclear Tests in Australia, 6.1.15, pp. 144-5.

12 Report of the Royal Commission into British Nuclear Tests in Australia, 6.1.20, p. 146.

13 Report of the Royal Commission into British Nuclear Tests in Australia, 6.1.17, p. 146.

14 Report of the Royal Commission into British Nuclear Tests in Australia, 6.1.22, p. 146.

15 Report of the Royal Commission into British Nuclear Tests in Australia, 6.1.19, p. 151.

16 Helen Chryssides, Local Heroes, Collins Dove, Melbourne 1993, p. 229.

17 Heather Goodall, 'Colonialism and Catastrophe: Contested Memories of Nuclear Testing and Measles Epidemics at Ernabella', in Kate Darian-Smith and Paula Hamilton, Memory and History in Twentieth Century Australia, Oxford University Press, Melbourne, 1994, p. 55.

18 Graeme Turner, 'Semiotic Victories: Media Constructions of the Maralinga Royal Commission', in John Frow and Meaghan Morris (eds), Australian Cultural Studies: A Reader, Allen \& Unwin, Sydney, 1993, p. 188.

19 Ibid., p. 186.

20 Ibid., p. 187.

21 Roslyn Haynes, Seeking the Centre: The Australian Desert in Literature, Art and Film, Cambridge University Press, Cambridge, 1998, pp. 66-7.

22 Ibid., p. 34.

23 Stephen Muecke, Textual Spaces: Aboriginality and Cultural Studies, New South 
Wales University Press, Sydney, 1992, pp. 5-6.

24 See, in particular, Len Beadell, Bush Bashers, Rigby, Adelaide, 1971, which deals with the construction of highways in central Australian and Len Beadell, Blast the Bush, Griffith Press, Adelaide, 1967, which is about the site selection and preparation for the atomic testing program.

25 Beadell, Bush Bashers, pp. 1-2.

26 Address by Len Beadell to the Annual Conference of Rotary District 982, Shepparton Rotary Club, Shepparton, Victoria, 2 March 1991, J. D. Somerville Oral History Collection, State Library of South Australia.

27 Address by Len Beadell to the Shepparton Rotary Club, 1991.

28 Christobel Mattingley, (editor and researcher) and Ken Hampton, (co-editor), Survival in Our Own Land: 'Aboriginal' Experiences in 'South Australia' since 1836, Hodder and Stoughton, Sydney, 1992; Lennon and Madigan, I'm the One that Know this Country!

29 Beadell, Blast the Bush, pp. 172.

30 Ibid., p. 210-11; Noel Sanders, 'The Hot Rock in the Cold War', in Ann Curthoys and John Merritt (eds), Better Dead Than Red: Australia's First Cold War, 1945-53, Allen \& Unwin, Sydney, 1984.

31 Royal Commission into British Nuclear Tests in Australia: Statements from Australian Witnesses A-D, National Archives of Australia, A6450.

32 'Nyila Nellie Wintinna', in Janet Skewes (ed.), Coober Pedylanguru Tjukurpa: Stories from Anangu of Coober Pedy, Umoona Community Council, Coober Pedy, 1997, p. 23.

33 'Jessie Lennon', in Skewes, p. 19.

34 'Ivy Stewart', in Skewes, pp. 41-2.

35 Yami Lester, Learning from the Land, Institute of Aboriginal Development Press, Alice Springs, 1995, pp. 8-10.

36 'Emily Austin', in Skewes, p. 31.

37 Stephen Muecke, No Road, Fremantle Arts Centre Press, Fremantle, 1997, p. 192.

38 Rose, p. 62.

39 Ibid., p. 70.

40 Ibid., p. 78.

41 Ibid., p. 73.

42 Talking Straight Out, p. 116. 